\title{
SUSTAINABILITY OF RAPID CHANGING ON SPATIAL AND URBAN POLICY OVER TRANSITIONAL PERIOD IN REPUBLIC OF MACEDONIA AND THEIR IMPACT ON INVESTMENTS
}

DOI: http://dx.doi.org/10.18509/GBP.2019.54

UDC: 330.322:[711.8:316.334.56(497.7)

\author{
Zaklina Angelovska ${ }^{1}$ \\ Strahinja Trpevski \\ ${ }^{1}$ Chamber of authorized architects and engineers, North Macedonia \\ ${ }^{2}$ Faculty of Architecture, University of "Ss' Cyril and Methodius" - Skopje, \\ Republic of North Macedonia
}

\begin{abstract}
During last decade, an extreme number of changes were introduced in the laws that define the Spatial Planning System for 85 municipalities and 8 regions, which is based on several key points: the social organization of the state, the planning regulations, the competences in spatial planning, Preparation and implementation of plans for urbanization of the area, types of planning documents, transparency and publicity in the procedures, competence and professionalism of the participants in the procedures, implementation of planning documents. General urban plans are strategic documents of public interest, and their adoption is mandatory and limits the construction only in urban areas with plans. This procedure means advancing with the way of managing, developing and building the space. However, in the absence of prepared plans, the same could be obstruction or an obstacle that proved later in practice because according to the law, the plans after the expiration of the 5-year deadline are considered undue and are the basis for illegal construction.

Changes in legislation on spatial planning, elaborated in this research, are presented with a chronology of the emergence of laws, basic features, in terms of establishing a new structure, respecting the principles of subsidiarity and hierarchy, while limiting the influence of the public, their needs and transparency. Hence it can be said that this represents the beginning of investment-oriented laws that have evolved to "customerbased law" to this day. In the last part of the survey, tables are presented that clearly show in this period how in practice urbanism was implemented through the adoption of detailed plans or planning documents that further serve for issuing building permits, investment planning and, finally, realized investments that are expressed as a parameter as part of the total GDP over the years.
\end{abstract}

Keywords: Spatial planning, general plan, urban planning, Low, investment,

\section{INTRODUCTION}

The need for spatial planning stems from the planned prediction of future activities in all spheres of human life, and especially in the sphere of organizing space as a limited resource. By applying spatial planning, by preparing and adopting appropriate spatial plans that plan the fundamental organization of space, research and determining guidelines for organizing the space at the state level, and by elaborating the established guidelines for development at the level of regions in frames of the state, at the level of municipalities or specific spatial units, whereby all entities in the concrete space have the 
basic framework of the future organization of the basic segments of the state space. Planning should take place in continuity and with a synchronized connection an optimal whole of the space is obtained.

Despite the fact that the Spatial Plan of Republic of Macedonia is the highest national document that organizes, protects and manages the space in the country, in other words, it is a "Constitution" for spatial planning and urbanization, the general conclusion is that our society does not attach importance to the spatial and urban planning of the space, as the basic segment of the country's development to the level it needs. It must harmonize the overall planning and urban documentation at all levels. The Spatial Plan of RM was adopted in 2004 and is valid until 2020.

Republic of Macedonia, existing in the past in another system and organization, as well as other ex-Yu republics from the region, in the post-transition period of almost 30 years, faces a relatively positive expansion of investments and the possibility of realizing natural potentials in the space that it has. The implementation of spatial plans is the weakest link of planning; it is insufficiently theoretically explored, methodologically un-positioned and in practice only partially carried out. The main direction in considering improvements in the implementation of plans is that it must be viewed and focused by means of spatial plans in order to as much as possible reduce the impact of all those factors outside the planning system.

Implementation in spatial planning can be defined in several ways. Bearing in mind the basic axiom of planning that making plans is only meaningful if they are going to be realized, it is expected from spatial planning that plans include and consider their realization. This axiom is acceptable, provided that at the very beginning the difference is clearly made between the terms "realization" and "implementation."[1]. The term "realization" refers to actual physical functioning in the space, while the term "implementation" has a wider meaning and includes not only the realization but also the whole range of conduct in accordance with and on the basis of the plan. It is therefore more acceptable to use "realization" for the construction of individual systems and facilities, which is the planning solution, or in the design and construction of a building, like in urban planning. "Implementation" is essentially more related to the spatial plans and the set of planning solutions that may include construction, policy and the strategy of behavior in space, as well as protection of space, the possibility of applying a rule, and so on, and it is therefore justifiable and necessary to use it for the purposes of spatial planning.

\section{CAHARACTERISTICS OF LEGAL FRAMEWORK FOR SPATIAL AND URBAN PLANNING}

In the period from the adoption of the Spatial Plan of the Republic Macedonia in 2004 to 2014 in a series of systematic measures that aimed at creating a favorable climate for investments, the emergence of new ones businesses and the dynamics of economic development, urban plans and projects are an important instrument, which provide spatial conditions for the development of entrepreneurship and the opening of small and medium enterprises which are the drivers of local and national economic growth and development with opportunities for employment of highly qualified and educated working population. According to the existing legislation in the field of spatial and urban planning, locating and displacing economic ones activities in the analyzed period was accomplished by the method of concentration and dispersion within the existing or emerging urban areas plans and projects. 
The extensive urban planning documentation, physical-geographical characteristics of the territory of the Republic of Macedonia, the overall economic and social development, long-term spontaneous movements in certain domains in space, the process of urbanization and the policy of the previous socialist system of planning and management in space led to economic polarization according to which the lines of development are mostly located in the areas that were formed in the years before and represent urban settlements.

In the conditions of the decentralization process, the units of the local self-government, undertake activities for providing adequate space for locating production and service facilities. According to their competencies in the area of urbanism, undertake measures for amending and supplementing valid documentation or preparation of new planning documentation for providing space for production and service purposes fully respecting the legal procedure for the preparation and adoption of urban plans.

At the same time, the characteristics of the market is the interest of foreign and domestic capital that imposes international project financing standards and the need to adapt to the increasing use of natural resources and renewable energy sources.

The basic spatial planning platform at central level is the Spatial Plan of the Republic of Macedonia, which is adopted by the Assembly of the Republic of Macedonia and which is worked out based on hierarchically lower documents for spatial planning (i.e. the spatial plan of the region and spatial plans for areas of special interest for the Republic).The process is managed by the Ministry of Environment and Physical Planning and the Agency for Spatial Planning.

At local level, the following documents are adopted: the General Urban Plan (GUP) (for the city of Skopje and for cities that are the seats of the municipalities); the Detailed Urban Plan (DUP) (on the planning scope for which a general urban design is adopted); Urban Design for a Village (UPS) (for the area of rural settlements in the municipality); urban designs for the outskirts of settlements (UPVNM) (when required for planning for the areas in municipalities that are not encompassed within the general urban designs and the village urban designs); the Architectural-Urban Project; and the Urban Project (for urban design of construction area that fall outside the scope of urban designs up to a level of feasibility study ). In order to understand the planning possibilities for the area, i.e. drafting urban plans, with exception of detailed urban plans, the plan designer is also obliged to demand conditions for spatial planning. GUPs, UPSs and UPVNMs are adopted based on the requirements for spatial planning issued in compliance with the Spatial Plan of the Republic of Macedonia.[2]

The process of designing the Spatial Plan of the Republic of Macedonia is centralized process. The municipalities do not have discretion to establish local development priorities. However, municipalities can establish these priorities in local plans by ensuring consistency with the objectives of the Spatial Plan of the Republic of Macedonia.

Local urban designs are adopted in two phases: draft and proposed designs. The drafts are subjected to expert revision. The process of adopting local urban designs is governed by the municipalities / the City of Skopje. Pursuant to legislation, the process is financed by the budgets of the municipalities / the City of Skopje. Local self-government units implement their competences through the authority competent for urban planning based on a programme that establishes the limitations and the content of the planning endeavor. The programme is adopted by the Municipal Council. The funds for the programme's implementation are established in the budget of the local self-government unit. The legal framework stipulates the publicity principle in the procedure of adopting and 
implementing the designs. The Ministry of Environment and Physical Planning has responsibility for supervising the implementation of the publicity principle in the work of the local self-government units, especially in terms of informing the public in a regular, timely and comprehensive manner. In order to ensure professionalism and publicity in the process of spatial and urban planning, the Municipal Council establishes a participative body that transfers the positions, opinions and needs of the citizens and legal entities, and monitors planning by giving initiatives, guidelines and suggestions for planning solutions in the given municipality. The participative body consists of: councilpersons, a representative from the municipal administration, a renowned expert in urban planning, representatives of civil associations and citizens of the municipality.

No Geographical Information System has yet been established in the planning regions. As a framework for overall development, however, it is planned in the strategic document for establishing the National Spatial Data Infrastructure (NSDI) of the Republic of Macedonia.

\section{FREQUENCY OF CHANGE OF LAWS ON SPATIAL AND URBAN PLANNING IN THE PERIOD BETWEEN 1990 AND 2016}

Through the quantitative analysis, the frequency of the changes of the Laws and their amendments are defined and additionally, the number of changes to the articles in the Laws are presented. Comparison is done for the number of words in the law and the total number of words of the changes in the law in the period prior to the adoption of the new law, as well as the analysis of the changes in the chapters in the Laws with a special focus on spatial planning and implementation of plans.

The initial analysis shown in Figure 1. gives a clear picture of the enormous frequency of the changes in the Law on Spatial and Urban Planning in the analysed period between 1990 and 2016. Between the adopted laws (1996/2005/2014) [3],[4],[5], three periods of change are formed. In the first period of the state's independence until the first law in 1996, three changes were made. In the second period from 1996 to the second law in 2005, seven changes were made. In the third period from 2005 to 2014, 15 changes were made, and after the adoption of the third - the new law on 31.12.2014 [5], in only two years until 2016, four changes were made. In the analysed period, it can be seen that 29 times the changes were made in the law, where we have changed twice in the same year, in 1996 [6] and 1997 [7], 2008 [8], 2014 [9], 2015 [10], [11] and 2016 [12], [13], three times in 2013 [14],[15],[16] and four times in 2011[17], [18], [19].

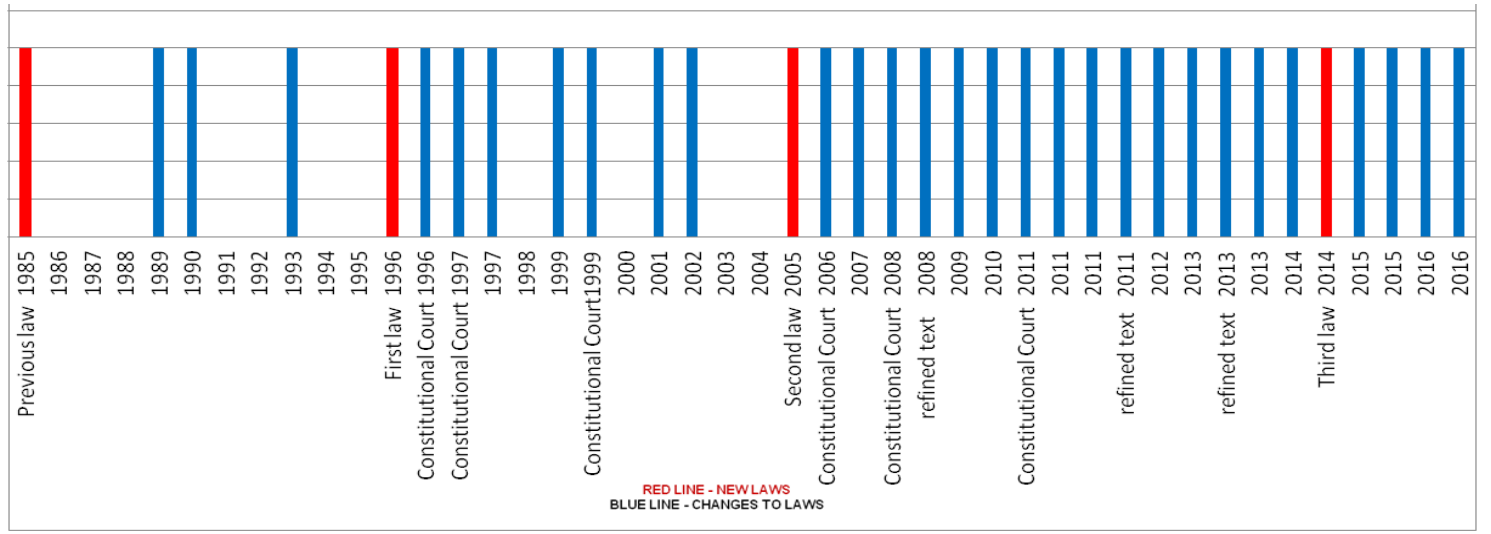

Figure 1. Frequency of changes in the Law on Spatial and Urban Planning for years from 1990 to 2016 
The established practice in spatial planning states, that for the establishment of a stable system in planning, a legal framework should cover a period of 20 years. Our practice with 29 amendments to three adopted laws for a period of 26 years, indicates a complete destabilization and degradation of the urban planning system.

Quantitative changes expressed by the number of changes in the articles presented in Figure 2.,gives even more explicitly the scope of the changes that conditionally make huge regulation in order for the system itself to enter into deregulation, i.e. it turns into lawlessness. New or amended 434 articles were made in the period from 1990 to 2016, or as an equivalent to a number of articles of the 2005 law [4], it represents a volume of five such laws. From this analysis, it is noted that the scope of the changes in the number of articles corresponds with the frequency of changes by years and it is especially expressed in the period from 2005 to 2016 with a total of 315 changes in articles representing $73 \%$ of the total changes in the observed period of years.

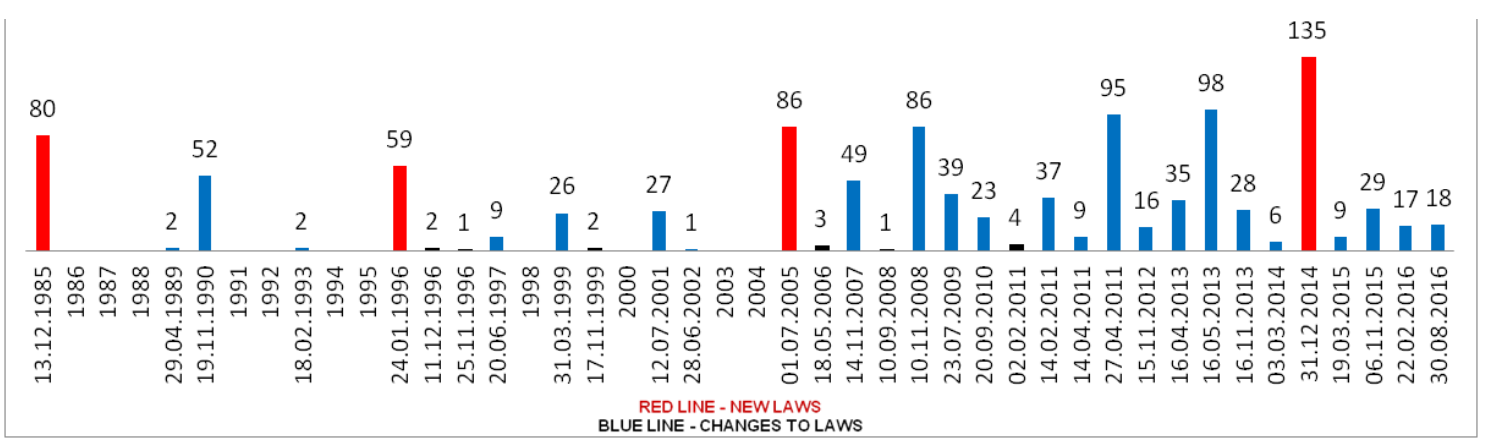

Figure 2. Number of changes of members in the law on spatial and urban planning for years from 1990 to 2016

Changes in the law on spatial and urban planning have created the latest Low from $2015,[10]$ with respect to the first from 1996,[3] to have 2.2 times more articles to regulate matter from the same area and the same space. The increased number of articles has created extensive regulation in urban planning while the continued change of articles causes deregulation of the urban planning system, that is difficult for implementation in practice and turns into lawlessness.

Continuing the quantitative analysis, by comparing the number of words in the law on spatial and urban planning and the total number of words of changes in the law in the period until the adoption of the new law (Figure 3.), shows that in the basic Low in 1996 there are seven chapters with 4,723 words.

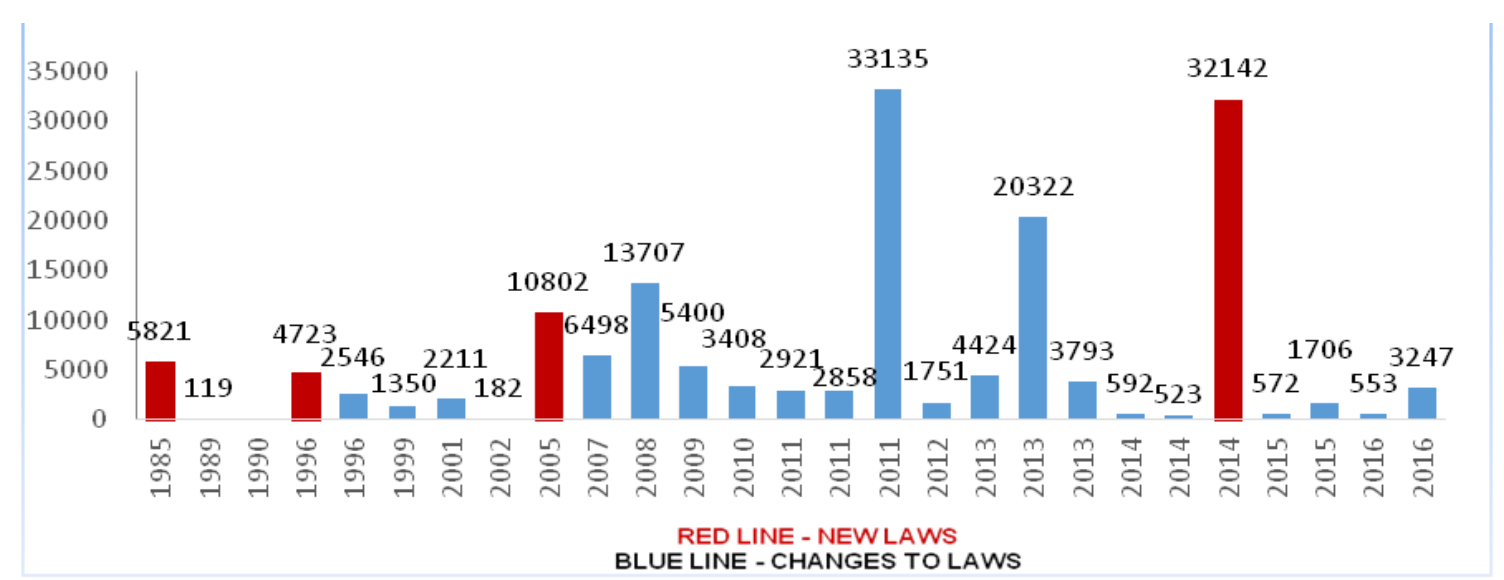

Figure 3. Number of words in the basic Low and number of words of changes in Low 
Pending the adoption of the next law in 2005, amendments were made with a total of 6,289 words or $133 \%$ increased volume of words in relation to the basic law. The 2005 Low has six chapters and 10,082 words. Until the adoption of the new law in December 2014, which has 14 heads, amendments have been made with a total of 32,168 words or $319 \%$ increased volume of words in relation to the previous law. Such enormous instability caused by the huge number of changes in continuity that is most evident in the period of 2005-2015, makes the system unsustainable, difficult to implement, it is impossible to monitor it professionally and the changes made are contrary to the principles of the nature of the changes. Recognizing the fact that the Low from 1996 has seven chapters with 4,723 words, and the last Law of 2015, [5] has fourteen chapters with 32,168 words or almost seven times more words or seven laws in a new one, makes it impossible professionally to monitor the legal and spatial changes, and thus the system of urban planning becomes unsustainable.

Focusing on the period in which the enormous changes to a single law (2005-2015)are done, broken down by the heads of the law (shown Figure 4-5), are given particular changes in the number of members in the ten-year period. There is no head, where no changes have been made in continuity. However, the focus of the changes that destructively affect the spatial and urban planning system is obvious, that is, Chapter 2Spatial Planning, where there are 234 changes to members or 5.5 times changed members of the basic chapter of the law. In Chapter 3 - Implementation of plans, the basic 9 members have changed 76 times or 8.4 times the members have changed in relation to the basic chapter. Chapter 5 - Penalty provisions in the Basic Law have 8 members, and 50 amendments have been made or 6,25 times the members have been changed in relation to the basic chapter. These essential changes affecting the system reflect a number of changes in members in other chapters such as: Chapter 1 - General Provisions, Chapter 4 - Oversight and Chapter 6 - Transitional and Final Provisions.

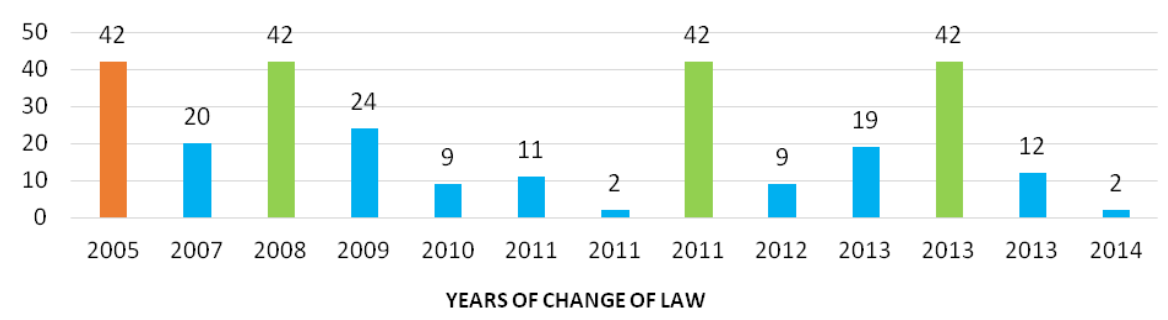

Figure 4. Number of changes of members in the law on spatial and urban planning for Chapter II

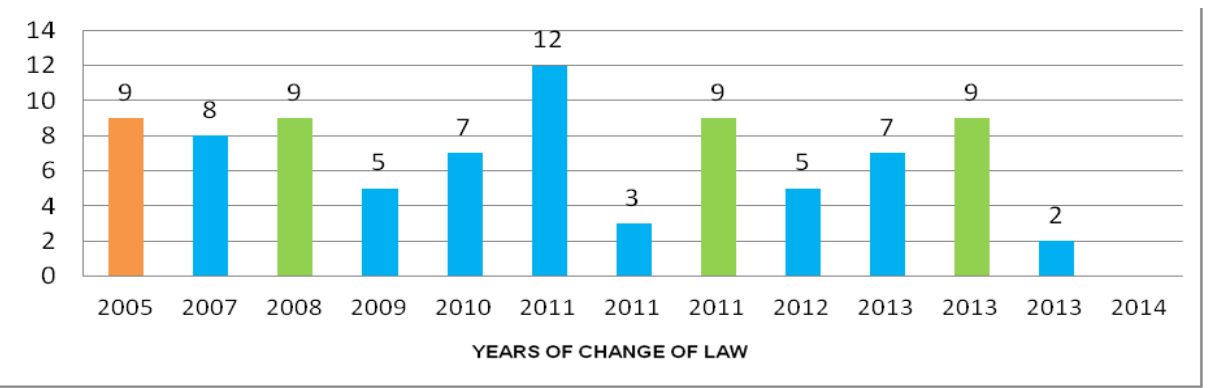

Figure 5. Number of changes of members in the law on spatial and urban planning for Chapter III 
This shows that the offered new solutions for urban planning in practice were not implemented well enough and quickly, therefore, extensive changes were made in that part, and in order to be successful, they were supported by penalty measures.

\section{ADOPTION OF URBAN PLANS THROUGH THE PROCESS OF CHANGES OF THE LOW WITH FINANCIAL IMPACT ON INVESTMENTS}

Considering that in the period between 2005 and 2015 three texts of Law on spatial and urban planning were made, the municipal authorities were obliged to adopt new detailed plans that would be in line with the legal changes. From the Table 1. it can be seen that in the given period, a total of 1117 plans were prepared and adopted, of which 40 are GUP, 1077 are DUP for the whole territory of the country. [20]

Table1. Statistical regions in RM with adopted DUP's and GUP's between 2006 and 2015

\begin{tabular}{|c|c|c|c|c|c|c|c|c|c|c|c|c|c|}
\hline \multicolumn{14}{|c|}{ APPROVED URBAN PLANS } \\
\hline Numb & REGION & URBAN PLANS & 2006 & 2007 & 2008 & 2009 & 2010 & 2011 & 2012 & 2013 & 2014 & 2015 & TOTAL \\
\hline & & & & & & & & & & & & & \\
\hline \multirow[b]{2}{*}{1} & \multirow{2}{*}{ PELAGONIJA } & DUP & 24 & 17 & 10 & 9 & 8 & 12 & 38 & 12 & 22 & 14 & 166 \\
\hline & & GUP & 2 & 3 & 3 & & 1 & 1 & & 1 & & & 11 \\
\hline \multirow[b]{2}{*}{2} & \multirow{2}{*}{ VARDAR } & DUP & 7 & 9 & 7 & 8 & 13 & 9 & 12 & 20 & 12 & 12 & 109 \\
\hline & & GUP & 2 & 1 & 4 & 1 & 1 & 2 & 1 & 1 & & & 13 \\
\hline \multirow[b]{2}{*}{3} & \multirow{2}{*}{ EASTERN } & DUP & 2 & 5 & 4 & 5 & 14 & 13 & 9 & 14 & 7 & 9 & 82 \\
\hline & & GUP & & 2 & & & & 1 & 1 & & & & 4 \\
\hline \multirow[b]{2}{*}{4} & \multirow{2}{*}{ SOUTHEASTERN } & DUP & 8 & 6 & 3 & 6 & 9 & 8 & 18 & 15 & 8 & 12 & 93 \\
\hline & & GUP & & & & & 2 & & & & & & 2 \\
\hline \multirow[b]{2}{*}{5} & \multirow{2}{*}{ SUBURBAN Skopje } & DUP & & 2 & 6 & 4 & 4 & 4 & 5 & 4 & & 5 & 34 \\
\hline & & GUP & & & & & & & & & & & \\
\hline \multirow[b]{2}{*}{6} & \multirow{2}{*}{ CITY SKOPJE } & DUP & 11 & 15 & 39 & 42 & 28 & 34 & 67 & 25 & 10 & 14 & 285 \\
\hline & & GUP & & & & & & & & & & & \\
\hline \multirow[b]{2}{*}{7} & \multirow{2}{*}{ SOUTHWESTERN } & DUP & 1 & 7 & 15 & 10 & 14 & 18 & 17 & 16 & 23 & 29 & 150 \\
\hline & & GUP & 1 & & & & 1 & 2 & & & & & 4 \\
\hline \multirow[b]{2}{*}{8} & \multirow{2}{*}{ POLOG } & DUP & 6 & 6 & 9 & 11 & 22 & 9 & 21 & 5 & 6 & 11 & 106 \\
\hline & & GUP & & & 1 & 4 & & & 4 & & & & 4 \\
\hline \multirow{5}{*}{9} & \multirow{2}{*}{ NORTHEASTERN } & DUP & 2 & 3 & 4 & 3 & & 2 & 1 & 2 & 19 & 16 & 52 \\
\hline & & GUP & & & & & & & 1 & 1 & & & 2 \\
\hline & TOTAL & DUP & 61 & 70 & 97 & 98 & 112 & 109 & 188 & 113 & 107 & 122 & 1077 \\
\hline & TOTAL & GUP & 5 & 6 & 8 & 5 & 5 & 6 & 7 & 3 & & & 40 \\
\hline & ALL TOTAL & & 66 & 76 & 105 & 103 & 117 & 115 & 195 & 116 & 107 & 122 & 1117 \\
\hline
\end{tabular}

It is a legal obligation every settlement to have a detailed urban plan that is adopted each 5 years. Every urban municipality has obligation to adopt a General Urban Plan each 10 years. Recognizing the latest data from the Statistical Office, in the Republic of Macedonia, there are 1784 settlements and 80 municipalities with urban or rural character, which in terms of the total adopted plans of 1117 represents only $60 \%$ coverage with planning documentation (Table1). If this is added to the need to amend and supplement the plans only in relation to the three refined texts of the Lows in the analyzed period from 2006-2015, then the total number of necessary new plans adopted would be 5592 or the existing ones adopted in relation to this required number of new adopted plans is only $20 \%$.If we make a comparison of adopted plans in all seven regions in the Republic of Macedonia with the two Skopje regions, we arrive at the data that a total of 319 urban plans have been adopted for the city and the region of Skopje, and a total of 758 plans have been adopted. In other words, from the total adopted plans in the period from 2006 to 2015 out of the 1077 plan, $30 \%$ are for the Skopje region, with the focus on the development of the city instead in equal spatial and regional development. [20]

If we analyze the number of adopted general urban plans, it can be concluded that with a total of 40 plans $50 \%$ of the city municipalities are covered, but when looking at the regions, it is noticed that only the Polog and the Vardar region have delivered several GUPs more than the number of the city municipalities in the region, which would mean 
that amendments were made to the GUP and not the adoption of a new GUP in line with the legal changes. In the eastern, northeastern and Polog regions, 50\% less GUPs from city municipalities were adopted. At least they were adopted in the southeast and northeast region, only 2 GUP. Observed as a whole in relation to the city municipalities, they are covered only with $30 \%$ in relation to general urban plans, and they are the basis for the preparation of the detailed urban plans.

In the dynamics of adopting plans from 2006 to 2015, there is a balance in the adoption of plans in the whole period, with the exception of double increase in the adoption of plans in 2012 (Table 1.) [20]. Recognizing the data from the previous Figure.4, it can be concluded that the increased number of adopted plans is due to the increased number of changes in the Law to 2011, especially in the segment of Spatial Planning - Chapter 2, where 150 changes were made in the articles.

The detailed urban plans and urban planning documents through which the strategic documents are implemented, have been adopted 946 plans over whole territory in all municipalities or average 11 plans per municipality in the Republic of Macedonia. Table 2 [21] and Table 3[22] clearly shows in the period between 2008/2015 how in practice urbanism was implemented through the adoption of detailed plans or planning documents that further serve to issue approvals for building construction, planning of investments and ultimately realization of investments. By analyzing and comparing dates from those tables, more results can be obtained concerning influence on economic growth of the country.

Table 2. Value of completed construction works over the period 2003-2015 and their participation/contribution in GDP of RM

\begin{tabular}{|c|c|r|r|c|}
\hline Years & $\begin{array}{c}\text { Value of completed } \\
\text { construction works in } \\
\text { euros/ } \begin{array}{c}€ \text { (at current } \\
\text { prices) }\end{array}\end{array}$ & $\begin{array}{c}\text { GDP in Euros/ } € \text { (at } \\
\text { current exchange rate) }\end{array}$ & $\begin{array}{c}\text { Participation of } \\
\text { Construction in } \\
\text { GDP in Euros / } €\end{array}$ & $\begin{array}{c}\text { Distribution/ } \\
\text { contribution to } \\
\text { GDP in \% }\end{array}$ \\
\hline 2003 & $302,149,739$ & $4,386,000,000.00$ & $218,856,431.75$ & 5.20 \\
\hline 2004 & $360,701,872$ & $4,578,000,000.00$ & $237,514,112.50$ & 5.30 \\
\hline 2005 & $374,321,823$ & $5,032,000,000.00$ & $257,151,154.82$ & 5.30 \\
\hline 2006 & $390,834,386$ & $5,472,000,000.00$ & $287,490,947.97$ & 5.50 \\
\hline 2007 & $363,855,390$ & $6,095,000,000.00$ & $340,585,313.07$ & 5.70 \\
\hline 2008 & $387,516,329$ & $6,772,000,000.00$ & $331,199,777.65$ & 4.90 \\
\hline 2009 & $373,639,052$ & $6,767,000,000.00$ & $347,883,158.42$ & 5.20 \\
\hline 2010 & $409,146,534$ & $7,109,000,000.00$ & $390,773,290.35$ & 5.50 \\
\hline 2011 & $444,542,283$ & $7,544,000,000.00$ & $393,685,425.59$ & 5.20 \\
\hline 2012 & $512,067,409$ & $7,585,000,000.00$ & $434,029,753.68$ & 5.70 \\
\hline 2013 & $613,772,929$ & $8,150,000,000.00$ & $580,847,085.60$ & 7.10 \\
\hline 2014 & $566,034,241$ & $8,562,000,000.00$ & $594,341,923.42$ & 6.90 \\
\hline 2015 & $670,170,382$ & $9,072,478,979.93$ & $645,408,374.84$ & 7.10 \\
\hline
\end{tabular}

In the period of 2008/2015, - 19,678 permits were issued for construction with expected value of the works of 4.95 billion Euros, out of which 3.94 billion Euros were actually realized and it is $20 \%$ less than expected.[22]. No clear correlation can be made between the number of adopted plans, the issued approvals, and the value of the investments / realization, since one issued building permit can be for an individual house or for a factory and a highway, that makes them uncomparable as investment value parameters. But, looking at the total investment by years, the GDP and the participation of construction in the formation of the GDP, then a clear picture is drawn of the share of investments, based on the urban plans in the creation of economic values, which has a direct impact on the 
development of the the state as a whole. From 2003-2012, the share of the construction sector in the creation of the GDP is 5.2-5.7\%. An increase in the percentage of participation in the formation of the GDP of 6.9-7.1\% was achieved only in 2012-2015.

Table 3. Statistical data for adopted urban plans, issued building permits by number and expected value of the works over the period 2008-2015

\begin{tabular}{|c|c|c|c|c|}
\hline Years & $\begin{array}{c}\text { Adopted } \\
\text { General } \\
\text { Urban Plan }\end{array}$ & $\begin{array}{c}\text { Adopted } \\
\text { Detailed } \\
\text { Urban Plan }\end{array}$ & $\begin{array}{c}\text { Total issued } \\
\text { permits for } \\
\text { construction }\end{array}$ & $\begin{array}{c}\text { Total expected } \\
\text { value of the } \\
\text { works in } \boldsymbol{\epsilon}\end{array}$ \\
\hline 2008 & 8 & 97 & 3463 & 462.763 .748 \\
\hline 2009 & 5 & 98 & 3074 & 386.493 .596 \\
\hline 2010 & 5 & 112 & 2854 & 450.903 .673 \\
\hline 2011 & 6 & 109 & 2596 & 467.500 .443 \\
\hline 2012 & 7 & 188 & 2794 & 843.808 .243 \\
\hline 2013 & 3 & 113 & 2269 & 461.609 .316 \\
\hline 2014 & 0 & 107 & 2628 & 1.132 .114 .072 \\
\hline 2015 & 0 & 122 & 3143 & 752.302 .326 \\
\hline & $\mathbf{3 4}$ & $\mathbf{9 4 6}$ & $\mathbf{1 9 . 6 7 8}$ & $\mathbf{4 , 9 5 7 , 4 9 5 , 4 1 7}$ \\
\hline
\end{tabular}

In economic theories, for a middle-developed country, a 25\% share of construction in the total GDP should be achieved if more economic growth is desired in society. The incomplete coverage with strategic plans and adopted DUPs are certainly one of the reasons for the low investment intensity and the low participation of construction in the formation of the GDP. These two parameters are in direct correlation with the development of the country and should be taken as indicators for measuring the success for the achieved economic growth and through investments for realized construction works.

\section{CONCLUSIONS}

The functioning of the legal system of spatial and urban planning depends on the rationality, the non-resistance, the economy and the appropriateness of the adoption of the laws, but also the time that they need to be accepted and properly applied by all participants in the process of planning, building and development of space. The pace, nature and structure of the changes in the regulation mostly influenced the quality, the process of preparation, adoption and implementation of the urban plans, and thus the realization of the basic constitutional objectives of the system, the planning of the space - the arrangement and humanization of the space and its development . According to the high dynamics of the change of the law, which is reflected through the scope and structure, the pace of preparation of the planning documentation as a basis for the development of the space, starting from the general level in the state to the lowest in the local self-government, is influenced. Due to the unnaturally increased pace of changing laws in this area, in the last decade there have been paradoxical phenomena in the system of planning and control of spatial development, such as the over-regulation in the legal acts and deregulation in their implementation. This in reality leads to serious disturbances in spatial planning, especially when it comes to strategic projects of interest at national and local level. Our adjustment of the system for the planning to the newly emerging social changes in the Republic of Macedonia in the period after the independence led to frequent changes and problematic competence of the participants in the process, supplemented by politics. Instead of improving the situation in the planning and development of the space, with the frequent and inadequate changes in the laws, it has 
adversely affected the established practice in urban planning and the process of its implementation. The basic mechanism for regulating and managing spatial development of the country is spatial and urban planning, through an integrated planning approach based on the principles of hierarchy, inclusiveness, harmoniousness and sustainable development of the whole. The main goal of the system is to provide the physical and spatial aspect of the development as a basis for the development of all aspects of life in the settlements. The planning regulation in its character covers a period of twenty years of spatial development on the territory of the state and only with such approach of a stable established system-legislation leads to economic progress and a sustainable development of the area, which is undoubtedly not the case with the Republic of Macedonia.

\section{REFERENCES}

[1] Nebojša Stefanović\&Boško Josimović \& Nataša Danilović Hristić, Models of Implementation of Spatial Plans: Theoretical Approach and Case Studies for Spatial Plans for the Special Purpose Area, http://dx.doi.org/10.5772/intechopen.78242, Republic of Serbia Chapter 4,pp 60-81

[2] Biljana Pulevska, Strategic concept- The role of spatial and urban planning for better climate change management, UNDP programme, pp,12-13, 2013

[3] Law on Spatial and Urban Planning ("Official Gazette of the Republic of Macedonia" No.04 dated 20.1.1996)

[4]Law on Spatial and Urban Planning - Consolidated Text (Official Gazette of the Republic of Macedonia No. 51 dated 1.7.2005).

[5] Law on Spatial and Urban Planning (Official Gazette of the Republic of Macedonia No. 199 from 30.12.2014).

[6]Decision of the Constitutional Court U.br.148/96 dated 11.12.1996).

[7]Law Amending the Law on Spatial and Urban Planning ("Official Gazette of the Republic of Macedonia" No.28 dated 20.6.1997)

[8]Law on Spatial and Urban Planning - Consolidated Text (Official Gazette of the Republic of Macedonia No. 24 dated 18.2.2008).

[9] Law Amending the Law on Spatial and Urban Planning ("Official Gazette of the Republic of Macedonia" No. 42 of 3.3.2014).

[10] Law Amending the Law on Spatial and Urban Planning ("Official Gazette of the Republic of Macedonia" No. 193 of 6.12.2015).

[11] Law Amending the Law on Spatial and Urban Planning ("Official Gazette of the Republic of Macedonia" No. 44 of 19.3.2015).

[12] Law Amending the Law on Spatial and Urban Planning ("Official Gazette of the Republic of Macedonia" No. 163 of 30.8.2016).

[13] Law Amending the Law on Spatial and Urban Planning ("Official Gazette of the Republic of Macedonia" No.31 of 22.2.2016).

[14] Law Amending the Law on Spatial and Urban Planning ("Official Gazette of the Republic of Macedonia" No. 163 of 26.11.2013).

[15]Law on Spatial and Urban Planning - Consolidated Text (Official Gazette of the Republic of Macedonia No. 70 dated 16.5.2013).

[16] Law Amending the Law on Spatial and Urban Planning ("Official Gazette of the Republic of Macedonia" No. 55 of 16.4.2013).

[17]Law on Spatial and Urban Planning - Consolidated Text (Official Gazette of the Republic of Macedonia No. 53 dated 27.4.2011). 
[18]Law Amending the Law on Spatial and Urban Planning ("Official Gazette of the Republic of Macedonia" No.18 dated 14.2.2011).

[19]Decision of the Constitutional Court U.br. 66/2010 of 2.2.2011

[20] Annual report on adopted urban plans in the Republic of Macedonia, State Inspectorate for Construction and Urban Planning of the Republic of Macedonia, 2016

[21] Gross domestic product: 2000-2012 revised data, State Statistical Office of the Republic of Macedonia, (Statistical review/State Statistical Office of the Republic of Macedonia, ISSN 0580454X. National economy and finances, ISSN 1409-7036; 3.4.14.04(793)), ISBN 978-608-227162-0, Table M-01.2.1 1, pp 36-37, 28.10.2014

[22] 25 years of INDEPENDENT MACEDONIA, State Statistical Office of the Republic of Macedonia, ISBN 978-608-227-238-2, (Macedonia-Economy-1991-2016, Statistical review, COBISS.MK-ID 101635850), pege 33, 07.09.2016 